\title{
Fluorometric Assay of DNA by Its Fluorescent Reaction with Chloroacetic Acid
}

\author{
Yuan-zong LI, Xiao-jing LiU, Hong-fei LiU, Hong-tao LiU and Yun-xiang Ci ${ }^{\dagger}$ \\ Department of Chemistry, Peking University, Beijing 100871, China
}

\begin{abstract}
A new fluorescent reaction of DNA with chloroacetic acid in the presence of triethylamine is proposed, and the reaction conditions have been optimized. Based on this fluorescent reaction, a sensitive fluorometric method is described for the determination of DNA and the selective determination of cytosine and dCMP. The detection limits for DNA, cytosine and dCMP were $6.0,0.4$ and $1.4 \mathrm{ng} / \mathrm{ml}$, respectively.
\end{abstract}

Keywords Fluorescent reaction, DNA, cytosine, dCMP, chloroacetic acid, triethylamine

It is well known that a variety of biochemical studies require the design and development of new reagents capable of recognizing and binding to specific regions of DNA, as well as a search for suitable techniques for the detection and identification of these DNA probes. Fluorometric methods have proven to be extremely useful for these kinds of studies. ${ }^{1}$

In some previous studies, a few fluorogenic reagents, such as a glyoxal hydrate trimer ${ }^{2,3}$ and chloroacetaldehyde $e^{4,5}$ were utilized for a sensitive and selective determination of a particular nucleic acid base and nucleos(t)ides. Recently, Kai et al. used alkoxyphenylglyoxals as fluorogenic reagents for selectively derivatizing guanine ${ }^{6}$ and 4-carbamoylbenzamidine for purine deoxyribonucleosides and nucleotides. ${ }^{7}$ All of these chemical derivatization reactions involved a first step involving an alkylation reaction and a second step involving a condensation reaction with ring-enclosing. However, very few studies concerning the reaction of nucleic acid with these types of fluorogenic reagents have been reported, except for a report on a fluorescence determination of DNA by derivatizing guanine and adenine bases with phenylglycal and chloroaldehyde, respectively. ${ }^{8}$

In this paper we report on a new fluorescent reaction in which DNA can react quantitatively with chloroactetic acid to form fluorescent products in the presence of triethylamine. Furthermore, since the fluorescent reaction has high selectivity and sensitivity toward cytosine and cytosine nucleotide it can be used for the sensitive determination of DNA and as well as the selective determination of cytosine and cytosine nucleotide. The detection limits for DNA, cytosine and dCMP were $6.0,0.4$ and $1.4 \mathrm{ng} / \mathrm{ml}$, respectively.

\footnotetext{
† To whom correspondence should be addressed.
}

\section{Experimental}

\section{Reagents and solutions}

Fish sperm (FS) DNA, cytosine, thymine, uracil, guanine, dCMP, AMP, TMP, UMP, GMP are Sigma products. Yeast RNA was obtained from Shanghai Biochemical Research Institute (China). Chloroacetic acid and triethylamine were obtained from Beijing Chemical Factory (China). All other chemicals were of analytical grade. A stock solution of DNA $(500 \mu \mathrm{g} / \mathrm{ml})$ was prepared by dissolving DNA in a $50 \mathrm{mM}$ sodium chloride solution.

Stock solutions of nucleic acid bases and nucleotides were prepared by dissolving them in distilled water.

\section{Apparatus}

Fluorescence spectra and intensities were measured on a Perkin Elmer LS-50B spectrofluorometer with a pulse xenon lamp and dual monochromators.

\section{Procedures for fluorescence measurements}

Typically, $10 \mu \mathrm{l}$ of a chloroacetic acid solution $(8 \mathrm{~mol} /$ 1), $10 \mu$ l of DNA solutions of different concentrations and $13 \mu \mathrm{l}$ of triethylamine were added to a $0.5 \mathrm{ml}$ centrifuge tube. The mixture was incubated in a thermostat water bath set at $100^{\circ} \mathrm{C}$ for $80 \mathrm{~min}$; then, $20 \mu \mathrm{l}$ of $\mathrm{HCl}(2 \mathrm{~mol} /$ 1) was added, and the mixture incubated at $100^{\circ} \mathrm{C}$ for $30 \mathrm{~min}$. At last, the reaction mixture was transferred to a $10 \mathrm{ml}$ comparison tube followed by the addition of a $1 \mathrm{ml} \mathrm{NaHCO}{ }_{3}-\mathrm{Na}_{2} \mathrm{CO}_{3}$ buffer solution $(\mathrm{pH}=10)$ and distilled water to the $5 \mathrm{ml}$ mark. Both the excitation and emission slits were maintained at $10 \mathrm{~nm}$. The maximum excitation and emission wavelengths were 320 and $360 \mathrm{~nm}$, respectively. The reported data are the average relative fluorescence intensities with the blank values subtracted except for those in the excitation and 


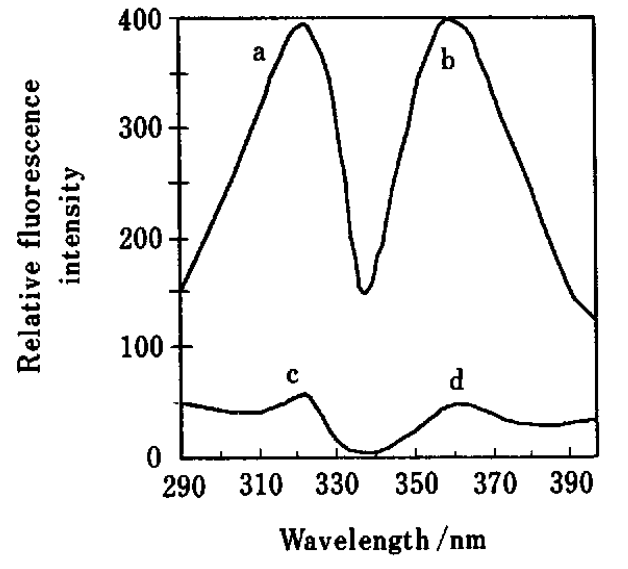

Fig. 1 Fluorescence spectra of the fluorescent product from $1 \mu \mathrm{g} / \mathrm{ml}$ DNA in $\mathrm{NaHCO}_{3}-\mathrm{Na}_{2} \mathrm{CO}_{3}$ buffer at $\mathrm{pH} 10$. Curves $a$ and $b$ are the excitation and emission spectra in the presence of DNA; $c$ and $d$ are those in the absence of DNA (blank).

emission spectra.

\section{Results and Discussion}

The excitation and emission spectra of the fluorescent product

The excitation and emission spectra of the reaction product in the presence and absence of DNA are depicted in Fig. 1. The excitation wavelength at $320 \mathrm{~nm}$ and the emission wavelength at $360 \mathrm{~nm}$ were optimal for obtaining the maximum fluorescent intensity, and were adopted for subsequent investigations.

\section{Optimization of reaction conditions}

The influence of different factors on the reaction was evaluated by measuring the fluorescence intensity of the product. Firstly, the influence of the chloroacetic acid concentration on the reaction was investigated using a constant amount of FS DNA and triethylamine $(1 \mu \mathrm{g} / \mathrm{ml}$ and $13 \mu \mathrm{l}$, respectively). The experimental results showed that the maximum fluorescent intensity could be obtained when the chloroacetic acid concentration was in the range of 7-9 mol/l. Therefore, $8 \mathrm{~mol} / \mathrm{l}$ chloroacetic acid was selected as the optimum.

Secondly, the influence of the amount of triethylamine on the reaction was further studied with a fixed concentration of chloroacetic acid $(8 \mathrm{~mol} / \mathrm{l})$ and FS DNA $(1 \mu \mathrm{g} / \mathrm{ml})$. The results showed that the maximum fluorescent intensity is reached when the volume of triethylamine is within the range of $10-15 \mu \mathrm{l}$. Meanwhile, the experimental results also showed that the reaction could not take place without triethylamine in the reaction system. A possible reason is that triethylamine was used as the proton acceptor to neutralize the released $\mathrm{HCl}$ from the reaction, thus helping to facilitate the reaction.

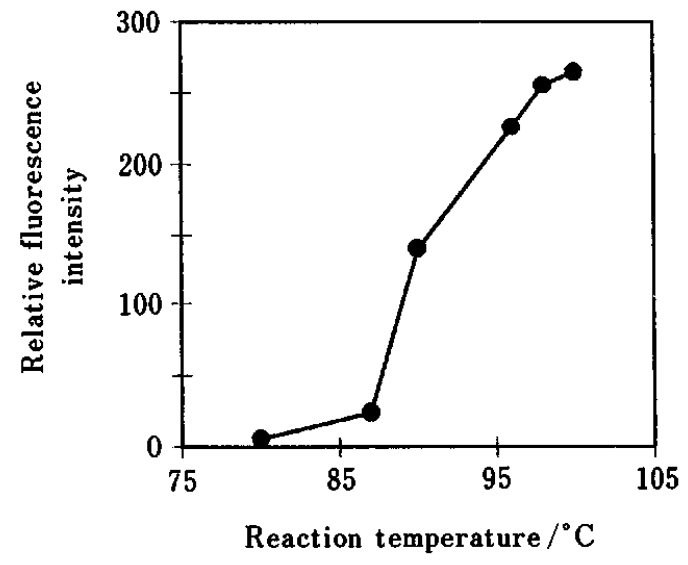

Fig. 2 Effect of the reaction temperature on the fluorescence intensity of the reaction product from $2 \mu \mathrm{g} / \mathrm{ml}$ DNA in a $\mathrm{NaHCO}_{3}-\mathrm{Na}_{2} \mathrm{CO}_{3}$ buffer at $\mathrm{pH} 10$.

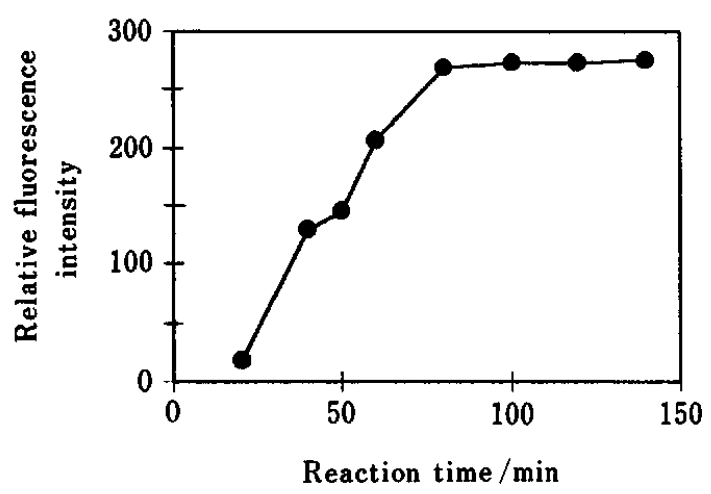

Fig. 3 Effect of the reaction time on the fluorescence intensity of the reaction product from $2 \mu \mathrm{g} / \mathrm{ml}$ DNA in a $\mathrm{NaHCO}_{3}-$ $\mathrm{Na}_{2} \mathrm{CO}_{3}$ buffer at $\mathrm{pH} 10$.

Thus, $13 \mu \mathrm{l}$ of triethylamine was used throughout this study.

The reaction temperature was examined over a range of $60-100^{\circ} \mathrm{C}$ with an $80 \mathrm{~min}$ reaction time (Fig. 2). A fluorescence-intensity measurement showed that the reaction can not take place below $80^{\circ} \mathrm{C}$. The reaction proceeded more rapidly at higher temperatures, ranging from 87 to $100^{\circ} \mathrm{C}$. The major reason may be that DNA began to denature at a temperature of around $87^{\circ} \mathrm{C}$. The reaction temperature was controlled at $100^{\circ} \mathrm{C}$ to obtain the maximum fluorescence intensity. Figure 3 shows the influence of the reaction time on the fluorescence intensity of the reaction product. This result indicates that the maximum fluorescence was reached when the reaction time was $80 \mathrm{~min}$. Above $80 \mathrm{~min}$, the fluorescence intensity was constant. Therefore, $80 \mathrm{~min}$ was selected as the optimum.

During our study we found that after the first reaction step the fluorescence intensity could be increased more 


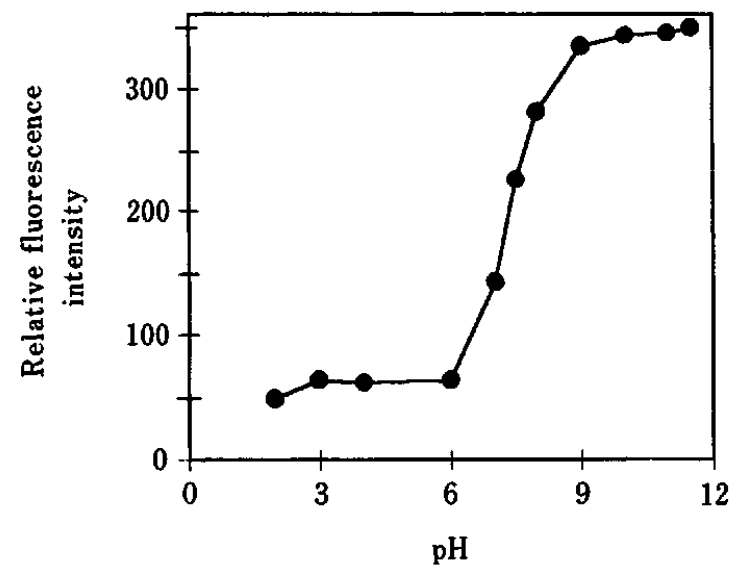

Fig. $4 \mathrm{pH}$ dependence of the fluorescent product from $1 \mu \mathrm{g} /$ ml DNA.

than one time by adding a certain amount of $\mathrm{HCl}$ to the reaction mixture and allowing the reaction to proceed at $100^{\circ} \mathrm{C}$ for an additional $30 \mathrm{~min}$. To gain a high sensitivity, the fluorescence intensity was further studied as a function of the concentration of $\mathrm{HCl} ; 20 \mu \mathrm{l}$ of $\mathrm{HCl}$ with different concentrations was added after the 80-min reaction mentioned in the experimental section, and the solution was further incubated at $100^{\circ} \mathrm{C}$ for $30 \mathrm{~min}$. The results showed that when the $\mathrm{HCl}$ concentration was increased the fluorescence intensity also increased. The fluorescence intensity reached the maximum with the $\mathrm{HCl}$ concentration at about $2 \mathrm{~mol} / 1$. In a subsequent study $20 \mu \mathrm{l}$ of $\mathrm{HCl}(2 \mathrm{~mol} / \mathrm{l})$ with $30 \mathrm{~min}$ incubation at $100^{\circ} \mathrm{C}$ was adopted.

\section{Optimization of the $\mathrm{pH}$ for fluorescence measurements}

The influence of $\mathrm{pH}$ on fluorescence measurement was studied and the result was showed in Fig. 4. From Fig. 4, it can be seen that the maximum fluorescence intensity occurs at $\mathrm{pH} 10$. Therefore, $\mathrm{pH} 10$ was chosen in this study.

\section{Reaction mechanism}

In order to understand this reaction based on the nucleic acid components, the reactions of chloroacetic acid with nucleic acid major bases and nucleotides were studied comparatively with nucleic acid under the established reaction conditions. The results are summarized in Table 1. These results show that no reaction was found with uracil, thymine, guanine, and their corresponding nucleotides. However, cytosine and cytosine nucleotide were found to react quantitatively with chloroacetic acid to form fluorescent products, and their fluorescent products have the same excitation and emission wavelengths as DNA's. The experimental results showed that although adenine also had a similar reaction $\left(\lambda_{\mathrm{ex}}=318 \mathrm{~nm}, \lambda_{\mathrm{em}}=362 \mathrm{~nm}\right.$ ), the sensitivity of the reaction was very low. That is, only at higher concentration of adenine could appreciable fluorescence from
Table 1 Relative fluorescence intensities from base, nucleotides and nucleic acids

\begin{tabular}{lclc}
\hline Compound $^{\mathrm{a}}$ & RFI $^{\mathrm{b}}$ & Compound & RFI $^{\mathrm{a}}$ \\
\hline Cytosine & 100 & UMP & 0 \\
Adenine & 4 & TMP & 0 \\
Thymine & 0 & PolyC & 25 \\
Uracil & 0 & PolyG $\cdot$ PolyC & 10 \\
Guanine & 0 & PolyA & 1.7 \\
dCMP & 80 & FS DNA & 43 \\
AMP & 0.8 & Yeast RNA & 14 \\
\hline
\end{tabular}

a. $0.4 \mu \mathrm{g} / \mathrm{ml}$ bases and nucleotides or $1 \mu \mathrm{g} / \mathrm{ml}$ nucleic acids were submitted to the reaction according to the established reaction conditions.

b. The relative fluorescence intensity (RFI) from cytosine was taken as 100 .

this reaction be observed. Adenine nucleotide had a much lower sensitivity than did adenine. In addition, from Table 1, it can be obviously seen that polynucleotides containing cytosine also exhibit a similar reaction.

These results indicated that the fluorescence in a DNA system is due to the reaction between chloroacetic acid and cytosine/adenine, similar to a previously reported reaction with chloroaldehyde as the derivative reagent. ${ }^{5}$ This reaction may follow a similar reaction mechanism as that proposed for the reaction between cytosine/adenine and chloroaldehyde.

In order to understand the reaction process between DNA and chloroacetic acid deeply, the reaction of cytosine, dCMP, with chloroacetic acid in the presence of triethylamine was also studied. The experimental results showed that the reaction condition of dCMP was similar to that of DNA, i.e. the reaction proceed at $100^{\circ} \mathrm{C}$ for $80 \mathrm{~min}$ to obtain the maximum fluorescence intensity. The difference between this reaction and that of DNA is that the reaction can take place at lower temperatures $\left(60-70^{\circ} \mathrm{C}\right)$. The experiment results again confirm that the first step of a reaction involving natural DNA may be the denaturation of DNA, which requires higher $\left(>80^{\circ} \mathrm{C}\right)$ temperature. The experiment results also showed that higher temperatures accelerate the reaction of DNA and dCMP with chloroacetic acid. The reaction condition of cytosine was different from those of DNA and dCMP. Firstly, the experimental results showed that the maximum fluorescence intensity could be obtained when the reaction temperature was controlled at $85^{\circ} \mathrm{C}$ and the reaction time was $60 \mathrm{~min}$. Secondly, although after the first reaction step the addition of $\mathrm{HCl}$ to the reaction systems of DNA and dCMP could increase the fluorescence intensity, the addition of $\mathrm{HCl}$ nearly had no effect on the cytosine's fluoresent reaction. The above experiment results suggested that the addition of $\mathrm{HCl}$ may make the derivatized base drop from DNA and dCMP molecules, forming the same fluorescent product as that in the reaction system of cytosine. The reason that the fluorescence increase upon adding $\mathrm{HCl}$ may have been due to the factor that the fluorescence intensity of 
fluoresent moiety in DNA and dCMP is lower than that in the released form. In addition, the influence of the pH on fluorescence measurements for cytosine and dCMP are the same as that for DNA, in agreement with the above proposal that the same product may be formed from the three reaction systems. Although the available information favors the proposed reaction mechanism, we are at present not able to confirm it; this will require additional work.

\section{Determination of DNA, cytosine and cytosine nucleotide}

Under the established reaction and measurement conditions, the quantitative determination of DNA by this fluorescent reaction was studied over a DNA concentration range of $0.01-2.0 \mu \mathrm{g} / \mathrm{ml}$. The calibration curve is linear within this range, and the detection limit is $6.0 \mathrm{ng} / \mathrm{ml}(S / N=2)$. The relative standard deviation ( 7 replicates) for the measurement of $1.0 \mu \mathrm{g} / \mathrm{ml}$ DNA is $4.8 \%$. The quantitative determinations of cytosine and dCMP based on the fluorescent reaction were also studied. Under their optimal conditions (described above), the

Table 2 Analytical parameters for the determination of DNA, dCMP and cytosine

\begin{tabular}{lcccc}
\hline Materials & $\begin{array}{c}\text { Linear range/ } \\
\mu \mathrm{g} \mathrm{m}^{-1}\end{array}$ & $\begin{array}{c}\mathrm{LOD}^{\mathrm{a}} / \\
\mathrm{ng} \mathrm{ml}^{-1}\end{array}$ & $\boldsymbol{r}^{\mathrm{b}}$ & $\mathrm{RSD}^{\mathrm{c}}, \%$ \\
\hline DNA & $0.010-2.000$ & 6.0 & 0.9988 & 4.8 \\
dCMP & $0.004-1.000$ & 1.4 & 0.9910 & 4.0 \\
Cytosine & $0.006-0.100$ & 0.4 & 0.9997 & 2.3 \\
\hline
\end{tabular}

a. Limits of detection (signal-to-noise ratio $=2$ ).

b. Correlation coefficient.

c. Relative standard deviation for seven measurement of $1 \mu \mathrm{g} / \mathrm{ml} \mathrm{DNA,} 0.2 \mu \mathrm{g} / \mathrm{ml} \mathrm{dCMP}$ and $0.045 \mu \mathrm{g} / \mathrm{ml}$ cytosine.

Table 3 Recovery of cytosine in other bases

\begin{tabular}{rcccccc}
\hline \multirow{2}{*}{$\begin{array}{c}\text { Bases/ } \\
\mathrm{ng} \mathrm{ml}^{-1}\end{array}$} & $\begin{array}{c}\text { Cytosine added/ } \\
\mathrm{ng} \mathrm{ml}^{-1}\end{array}$ & \multicolumn{5}{c}{$\begin{array}{c}\text { Recoveries of cytosine in } \\
\text { different base, \% }\end{array}$} \\
\cline { 3 - 7 } & & $\mathrm{T}$ & $\mathrm{U}$ & SFU & G & A \\
\hline 50 & 50 & - & - & - & - & 100.3 \\
250 & 50 & - & - & - & - & 111.0 \\
500 & 50 & 100.3 & 100.7 & 99.7 & 101.7 & 135.0 \\
\hline
\end{tabular}

Table 4 Recovery of dCMP in other nucleotides

\begin{tabular}{cccccc}
\hline \multirow{2}{*}{$\begin{array}{c}\text { Nucleotide/ } \\
\text { ng ml }^{-1}\end{array}$} & $\begin{array}{c}\text { dCMP added/ } \\
\text { ng ml }^{-1}\end{array}$ & \multicolumn{4}{c}{$\begin{array}{c}\text { Recoveries of dCMP in } \\
\text { different nucleotide, \% }\end{array}$} \\
\cline { 3 - 6 } & & TMP & UMP & GMP & AMP \\
\hline 50 & 50 & - & - & 106 & 98 \\
250 & 50 & - & - & 95 & 102 \\
500 & 50 & 94 & 108 & 108 & 125 \\
\hline
\end{tabular}

calibration curves are linear in the range of $0-100 \mathrm{ng} / \mathrm{ml}$ and $0.004-1.0 \mu \mathrm{g} / \mathrm{ml}$, respectively, for cytosine and dCMP. The detection limit for cytosine is $0.4 \mathrm{ng} / \mathrm{ml}$, and for dCMP it is $1.4 \mathrm{ng} / \mathrm{ml}(S / N=2)$. The relative standard deviation (7 replicates) for the measurement of $45 \mathrm{ng} / \mathrm{ml}$ of cytosine it is $2.3 \%$, and for the measurement of $200 \mathrm{ng} / \mathrm{ml}$ of dCMP is $4.0 \%$. Due to the specificity of the reaction to cytosine and cytosine nucleotide, it is expected that the cytosine and cytosine nucleotide could be measured in the presence of other bases and other nucleotides. Their recoveries are summarized in Tables 2 and 3. Table 2 shows that a 10 times excess of thymine, uracil and guanine has no interference on the cytosine determination, while a 10-time excess of adenine has some interference. Table 3 shows that a 10-time excess of dTMP, GMP, UMP nearly has no interference on the dCMP determination, while a 10-time excess of adenine nucleotide shows a light interference.

In conclusion, a new fluorescent reaction is proposed for DNA. The fluorescent reaction has high selectivity toward cytosine and cytosine nucleotide. The detection limits for cytosine and dCMP are 0.4 and $1.4 \mathrm{ng} / \mathrm{ml}$, respectively. The previous literature reported that the detection limit for cytosine nucleotide was $1.0 \mu \mathrm{mol} / 1$ when chloroacetaldehyde was utilized as a derivatizing reagent. Therefore, the sensitivity of the method reported in this paper was 25-times higher than that mentioned in a previous report. ${ }^{8}$ The new fluoresent reaction may thus be used for the sensitive determination of DNA and the selective determination of cytosine and cytosine nucleotide in the presence of other bases and other nucleotides with high repeatability. In addition, the reaction may be employed for comparing of the cytosine content in different samples.

This work was supported by National Natural Science Foundation of China (29575191).

\section{References}

1. M. A. Martin, B. del Castillo and J. C. Menendez, Anal. Lett., 24, 1503 (1991).

2. H. Yuki, C. Sempuku, M. Park and K. Takiura, Aanl. Biochem., 46, 123 (1972).

3. H. Yuki, C. Sempuku, M. Park, H. Isemura and K. Takiura, Anal. Biochem., 48, 290 (1974).

4. J. R. Barrio, A. Secrist and N. J. Leonard, Biochem. Biophys. Res. Commun., 46, 597 (1972).

5. J. Biernat, J. Ciesiolka, P. Gornicki, W. J. Krzyosiak and M. Wiewiorowski, Nucleic Acids Res., 4, 203 (1978).

6. Y. Ohba, M. Kai, H. Nohta and Y. Ohkura, Anal. Chim. Acta, 287, 215 (1994).

7. M. Kai, F. Toba, H. Nohta and Y. Ohkura, Microchem. J., 49, 165 (1994).

8. M. Kai, S. Yonekura, H. Nohta, M. Iwasaki and Y. Ohkura, Anal. Sci., 10, 253 (1994).

(Received October 21, 1996) (Accepted January 13, 1997) 